\title{
Internet Access and Internet Self-efficacy of High School Students
}

\author{
Wayan Suana ${ }^{1}$, Afif Rahman Riyanda ${ }^{2}$, Ni Made Anggi Arlina Putri ${ }^{3}$ \\ ${ }^{1}$ Physics Education Program, Universitas Lampung, Indonesia \\ Email:wsuane@gmail.com \\ ${ }^{2}$ Information Technology Education Program, Universitas Lampung, Indonesia \\ Email: afif.rahman@fkip.unila.ac.id \\ ${ }^{3}$ Independent Researcher, Bandar Lampung, Indonesia \\ Email: nimadeanggi@gmail.com
}

(Received: February-2019; Reviewed: April-2019; Accepted: June-2019; Published: August-2019)

\begin{abstract}
This study aimed at determining the availability of the internet facility, access, and internet usage in general as well as in learning physics among high school students in Lampung, Indonesia. The study also assessed students' internet self-efficacy and perception of the internet in learning physics. A number of 1883 students, which consists of 700 males and 1183 females, participated in this descriptive study. A questionnaire consisted of 30 items was implemented in this study. The results showed that most students have internet facilities and nearly all of them have internet access through mobile phones. The majority of students had used the internet for more than or equal to three years $(78.1 \%)$. In using the internet, students have two main reasons, for academic purposes (90.3\%) and for social media activities (89.5\%). Majority of internet service used in physics was to solving homework (78.5\%). The study also revealed that students" internet self-efficacy and perception for learning physics were in "high" and "positive" category, respectively. These results imply that the students' internet facilities, access, experience, and self-efficacy are categorized high. Therefore, the integration of internet in teaching physics at high school in Lampung is adequately potential.
\end{abstract}

Keywords: Internet access; Internet self-efficacy; Perception about internet; Physics learning

\section{INTRODUCTION}

In recent year, due to its explosive growth, the internet has become increasingly important for diverse needs of human's life (Wastiau, et al., 2013; Chou et al., 2009). The data of the internet user population worldwide by 31 March 2017 is 3,731,973,423, almost a half $(49.6 \%)$ of the total population in the world. Moreover, in Indonesia, the population of internet users is $132,700,000$, more than half $(50.4 \%)$ of the total population in Indonesia (Miniwatts Marketing Group, 2017). The reasonable factors explaining this phenolmenon is that internet provides all needs of source such as information, education, communication, and entertainment, as mention in some literature ( see e.g. Rhema \& Miliszewska, 2014; Jadoon et al., 2011).

Furthermore, it has been introduced as a powerful tool and rich information sources for academic works (Jimoyiannis, 2010; Chou et al., 2009). Internet is also stated as multiple tools which enable students to communicate with others and share knowledge, experience, and culture (Limaye \& Fotwengel, 2015). Consequently, the use of internet plays a crucial role in sustaining educational practice (Rhema 
\& Miliszewska, 2014).

Based on some studies, the efficiency and effectiveness of accessing material on the internet may become one of the reasons for internet usage trends among user (Limaye \& Fotwengel, 2015; Jadoon et al., 2011; Tsai et al., 2011). Comparing to conventional environment learning, Internet-based learning (IBL) provides different learning experiences for learners, more cost-efficiently or positive outcome quality (Abdous \& Yoshimura, 2010). The finding of studies suggests that sustaining learning process by technology can improve students' achievement, skill, positive attitude and also gain more knowledge within the process (John, 2015; Tsai et al., 2011).

In the other hand, a study of integrating YouTube video in teaching Chemistry by Blonder et al. (2013) found that the educators improve their skill, and even more creative in developing a unique Technological pedagogical and content knowledge (TPACK). Moreover, it is noted, by offering opportunities of innovation, communication channels, flexibility of time, and also social system, IBL suggests improving teachers' motivation in internet utilization in teaching-learning process (Uluyol \& Şahin, 2016).

Besides, in order to get efficient implementation, there are several things to need under attention. A study in Pakistan found that instead of more than $80 \%$ students were able to use internet, the frequency of internet use and its usage in learning were still low due to the lack of training of students in comparison with other countries (Jadoon et al., 2011). In terms of its outcomes derived from IBL, several studies revealed that student's self-efficacy and students' perception toward the internet have had a positive role in learning outcome (Tsai et al., 2011; Tsai \& Lin, 2004; Wu \& Tsai, 2006). Further investigation reveals that hardware, software, learning material, and also documentation are all the needs in integrating ICT in teaching-learning process (Tondeur et al., 2012).

Regarding the internet-based learning term, computer belief play a significant role in technology acceptance (Wong et al., 2012). Research has proved that students' self-efficacy has an important role in students' attitudes, process, and outcomes (Tsai et al., 2011). These are in line with the work by Celik and Yesilyurt (2013) that ICT self- efficacy is important in computer-based learning. There is a positive relationship between students' IT self-efficacy and the use e-learning, computer skill, attitude, and also students' outcomes (Baturay, et al., 2017; Wu, Tennyson, \& Hsia, 2010). In sum, self-efficacy is an important concept in the research of ICT and is usually used to represent the actual skill which is comparatively difficult to measure.

Due to the limitation research in Indonesia regarding inernet utilisation, this study was, therefore, aimed at determining the patterns of internet access and utilization among high school students undergoing physics learning. Furthermore, highlighting the importance of self-efficacy role in the learning process, the study also assessed the general internet self-efficacy of students and students' perception of internet usage in physics learning, in Indonesia.

\section{METHOD}

The survey study was carried out at 23 senior high schools in Lampung Province of Indonesia which a random sampling was implemented. The sample for each school was between 70 to 93 students from 23 schools. From a total of 23 schools, 10 schools were from the city of Bandar Lampung and Metro, and the rest were from remote areas. A number of 1883 participants in total, which were 700 male students and 1183 female students involved in this study. From the whole participants, 691 were first-year students, 727 were second-year students, and 465 were thirdyear students.

For the aim of the study, a Questionnaire used consisted of 30 items was prepared for a survey. It elicited information about students' demographic profile (3 items), internet facility both at school and at home (5 items), internet access, general utilization and in physics learning utilization (6 items), internet self-efficacy scale (10 items), and perception of internet in physics learning (6 items). This instrument was adapted the Internet SelfEfficacy Scale (ISES) developed by Tsai \& Tsai (2003) and Wu \& Tsai (2006) which modified the scale to a ten-item 5-point Likert-type scale ranging from 5 (very confident) to 1 (very unconfident). All of these items measured general Internet self-efficacy (GISE) which is related to a respondents' confidence about their basic skills in operating Internet function.

Pearson correlation was used to measure 
the validity, and the result was valid for its entire item. Test of reliability of scale has been conducted by measuring Cronbach alpha. With the coefficient of .857, the questionnaire was considered reliable as they surpassed the minimal consistency guidelines (> .60). The validity of the perception scale was also valid for all items. Test of reliability of perception scale has also been conducted by measuring Cronbach alpha. Since the Cronbach alpha coefficient was .667, then the questionnaire was also considered reliable.

\section{RESULT AND DISCUSSION}

\section{Result}

In term of socio-demographic, a number of 1883 senior high-school students from different grade were selected as participants. The majority participant in this study was female (1183 students) which was taking 62.8\% while 700 students $(37.2 \%)$ of all were males. The students were from grade $\mathrm{X}(36.7 \%)$, grade XI (38.6\%), and grade XII (24.7\%).

Table 1. Students' Internet Facility

\begin{tabular}{|c|c|c|c|}
\hline $\mathrm{No}$ & Item & $\mathrm{n}$ & $\%$ \\
\hline \multirow[t]{3}{*}{1} & \multicolumn{3}{|c|}{ Availability of internet devices } \\
\hline & -Yes & 1309 & 69,5 \\
\hline & $-\mathrm{No}$ & 574 & 30,5 \\
\hline \multirow[t]{3}{*}{2} & \multicolumn{3}{|c|}{ Internet connection at home } \\
\hline & - Yes & 855 & 45,4 \\
\hline & $-\mathrm{No}$ & 1028 & 54,6 \\
\hline \multirow[t]{3}{*}{3} & \multicolumn{3}{|c|}{$\begin{array}{l}\text { Internet connection through } \\
\text { smartphones }\end{array}$} \\
\hline & -Yes & 1766 & 93,8 \\
\hline & $-\mathrm{No}$ & 117 & 6,2 \\
\hline \multirow[t]{4}{*}{4} & \multicolumn{3}{|c|}{ Internet connection at school } \\
\hline & -Sufficient & 787 & 41,8 \\
\hline & -Not sufficient & 1051 & 55,8 \\
\hline & -None & 45 & 2,4 \\
\hline \multirow[t]{4}{*}{5} & Wifi at school & & \\
\hline & -Yes, with good speed & 554 & 29,4 \\
\hline & -Yes, with bad speed & 1213 & 64,4 \\
\hline & -None & 116 & 6,2 \\
\hline
\end{tabular}

Due to investigating the students' internet self-efficacy, the present study had also analyzed students' internet facility at home and school. Based on Table 1, nearly $70 \%$ of students stated that they had their own computer or laptop at home where only $45.4 \%$ have internet connection. A large number of students (93.8\%) stated they have internet connection through smartphone/mobile phones. The students reported that even their school had internet service but it was not sufficient for all of the students. Normally, the number of computer with internet connection at a particular school is much less than the number of their students. The availability of wifi at schools in Lampung is also growing, more than $90 \%$ of students stated their schools have wifi, but the speed is still lacking.

The result related to the experience of students' internet use is shown in Table 2. Most participants had used internet for more than or equal to 3 years $(78.3 \%)$ and less than $5 \%$ of them assessed internet less than a year. At the same table with students' experience of the internet use, results of study about the frequency of internet use depict that almost three-fourth (74.1\%) students used internet every day, $15 \%$ of them used internet 3-4 times/week, 5.4\% for once a week, and the rest only about $5 \%$ of students use internet 2-3 times per month or less. This initial finding is relevant to a study conducted by Ayub et al. (2014) which also found that students internet access time are different based on level and field of study. Loan (2011) who conducted a comparative study of internet used by rural and urban college students found that as compared from daily to weekly $84.70 \%$ of urban students were frequent users of internet than rural students $(73.95 \%)$.

Table 2. Experience and frequency of Internet Use

\begin{tabular}{|c|c|c|c|}
\hline No & Item & $\mathrm{n}$ & $\%$ \\
\hline \multirow[t]{8}{*}{1} & Experience of Internet & & \\
\hline & Use & & \\
\hline & $>5$ years & 795 & 42,2 \\
\hline & $4-5$ years & 358 & 19 \\
\hline & 3-4 years & 322 & 17,1 \\
\hline & $2-3$ years & 205 & 10,9 \\
\hline & $1-2$ years & 119 & 6,3 \\
\hline & $<1$ year & 84 & 4,5 \\
\hline \multirow[t]{8}{*}{2} & Frequency of Internet & & \\
\hline & Use & & \\
\hline & Daily & 1395 & 74,1 \\
\hline & 3-4 times/week & 288 & 15,3 \\
\hline & Once a week & 102 & 5,4 \\
\hline & 2-3 times/month & 58 & 3,1 \\
\hline & Once a month & 23 & 1,2 \\
\hline & Never & 17 & 0,9 \\
\hline
\end{tabular}

Moreover, the variation of accessing the internet was also examined in this study. The data discloses that using internet at home was 
identified as the preferred place by students $(85.1 \%)$ for both social and academic supporting service, followed by school (64.4\%), and commercial cyber cafes $(42.1 \%)$. It is generally speaking that Indonesian students mostly used internet at home. The same argument is also reported by Jadoon et al. (2011) who found $70.5 \%$ of students' preferred using internet at home. This finding is also relevant to Zhao et al. (2010) who stated that home and cafe are considered as the main location for students to use the internet. In other hands, Loan (2011) found that the majority of urban students used internet at commercial cybercafés while rural students mainly used internet at home.

Table 3. Purpose of Students' Internet Use

\begin{tabular}{clll}
\hline No & $\begin{array}{l}\text { Purpose of internet use } \\
\text { by students }\end{array}$ & $\mathrm{n}$ & $\%$ \\
\hline 1 & Academic & 1700 & 90,3 \\
2 & Social Media & 1685 & 89,5 \\
3 & Online Shopping & 518 & 27,5 \\
4 & Email & 565 & 30 \\
5 & Chatting & 1077 & 57,2 \\
6 & Online Reading & 426 & 22,6 \\
7 & Entertainment & 1288 & 68,4 \\
8 & Downloading & 938 & 49,8 \\
9 & E-learning & 298 & 15,8 \\
10 & General information & 1254 & 66,6 \\
11 & Other & 30 & 0.6 \\
\hline
\end{tabular}

In using the internet, people have various reasons to use the internet (Table 3 ). For example, the present study noted that students used internet more for academic purposes $(90.3 \%)$ and social media activities (89.5\%) followed by entertainment $(68.4 \%)$, getting general information $(66.6 \%)$, and chatting $(57.2 \%)$, as top 5 activities. The result also revealed that there is $15.8 \%$ of students (298 students) who used internet to join e-learning. The reason might be that there is not enough information about what and how to join it.

Table 4. Internet Use in Physics Learning

\begin{tabular}{llll}
\hline No & $\begin{array}{l}\text { Internet service used by } \\
\text { students in Physics }\end{array}$ & $\mathrm{n}$ & $\%$ \\
\hline 1 & $\begin{array}{l}\text { Browsing of physics } \\
\text { material }\end{array}$ & 1228 & 65,2 \\
2 & Searching of physics video & 375 & 19,9 \\
3 & $\begin{array}{l}\text { Searching of physics } \\
\text { animation }\end{array}$ & 330 & 17,5 \\
4 & Doing homework & 1478 & 78,5 \\
5 & Joining e-learning/online & 171 & 9,1 \\
\hline
\end{tabular}

\begin{tabular}{llll}
\hline & learning & & \\
6 & Engage in discussion group & 284 & 15,1 \\
7 & Searching of physics & 981 & 52,1 \\
& exercises & & \\
8 & Doing exercises & 424 & 22,5 \\
9 & Other & 23 & 1,2 \\
\hline
\end{tabular}

Internet service used by students in Physics was also examined in the present study. Based on the data showed in Table 4, the students used internet in order to solve their problem in doing homework. It was found as the most reason of using internet $(78.5 \%)$. They also used internet for browsing of Physics material (65.2\%), searching Physics exercises (52.1\%), doing Physics exercises (22.5\%), searching of Physics animation (17.5\%), and engage in discussion groups (15.1\%). Deb (2011) also noted that students' internet use related to their studies. This fact of internet used by students for various reasons may also be related to internet use as a powerful tool and rich information sources for academic works (Chou et al., 2009).

Despite all the advantages above, internet also leaves some barriers. Since Indonesia is a developing country, the speed of internet connection still lacks to support students' internet utilization. The present study provides a preliminary evaluation of problems faced by students in using internet. As it is shown in Table 5, the poor internet connection was found as the most common problem faced by students in using internet (85.8\%). Furthermore, the expensive cost that students must be paid for internet access was also identified as barriers $(28.6 \%)$. As stated by Zhao et al. (2010), in some developing countries, insufficient facilities at school or unaffordable expenses for internet access at home are problems faced by students in using internet. Moreover, the students also need to have the skill to analyze and choose data due to a large amount of data on internet (22.7\%).

Table 5. Barriers to Accessing the Internet

\begin{tabular}{clll}
\hline No & Item & $\mathrm{n}$ & $\%$ \\
\hline 1 & Poor internet connection & 1616 & 85,8 \\
2 & Hard to find information & 606 & 32,2 \\
3 & Too much information & 427 & 22,7 \\
4 & Lack of time to used & 117 & 6,2 \\
5 & High cost & 539 & 28,6 \\
6 & Other & 43 & 2,3 \\
\hline
\end{tabular}


Table 6. Internet Self-efficacy

\begin{tabular}{|c|c|c|c|}
\hline No & Question & mean & $\mathrm{SD}$ \\
\hline 1 & $\begin{array}{l}\text { I know how to search the } \\
\text { web? }\end{array}$ & 4,28 & 0,76 \\
\hline 2 & $\begin{array}{l}\text { I am able to look for } \\
\text { information in the website? }\end{array}$ & 3,97 & 0,82 \\
\hline 3 & $\begin{array}{l}\text { I can use web browser like } \\
\text { Mozilla Firefox to search } \\
\text { for information }\end{array}$ & 4,08 & 0,85 \\
\hline 4 & $\begin{array}{l}\text { I believe that I am a good } \\
\text { user of the internet }\end{array}$ & 4,11 & 0,82 \\
\hline 5 & $\begin{array}{l}\text { I believe I can access more } \\
\text { than one site at the same } \\
\text { time }\end{array}$ & 4,12 & 0,84 \\
\hline 6 & $\begin{array}{l}\text { I believe I can enter URL } \\
\text { site directly to open web }\end{array}$ & 3,89 & 0,93 \\
\hline 7 & $\begin{array}{l}\text { I believe I can make } \\
\text { bookmark for important } \\
\text { web }\end{array}$ & 3,26 & 1,04 \\
\hline 8 & $\begin{array}{l}\text { I believe I can print out } \\
\text { important information from } \\
\text { web }\end{array}$ & 3,85 & 0,98 \\
\hline 9 & $\begin{array}{l}\text { I believe I can download } \\
\text { file from internet }\end{array}$ & 4,09 & 0,89 \\
\hline \multirow[t]{2}{*}{10} & $\begin{array}{l}\text { I believe I can copy texts } \\
\text { from web to Microsoft } \\
\text { Word }\end{array}$ & 4,38 & 0,83 \\
\hline & Average & 4,00 & 0,88 \\
\hline
\end{tabular}

Related to the use of internet, students' attitude and self-efficacy toward the internet have an important effect on their motivation and interest of learning using internet (Agyei \& Voogt, 2011). By means of the influences, the present study also explores senior high school students' internet attitudes and internet selfefficacy generally. This study reveals that students' internet self-efficacy and perception about internet were high and positive. According to the results presented in Table 6 and Table 7, the average of ISE was 4.00 which mean students have high ISE, and 3.71 of internet perception means that students have a positive perception of internet for learning Physics.

Table 7. Perception about the Internet Usage in Physics Learning

\begin{tabular}{llll}
\hline No & Item & mean & SD \\
\hline 1 & $\begin{array}{l}\text { Internet helps me to find } \\
\text { physics materials }\end{array}$ & 4,29 & 0,69 \\
2 & $\begin{array}{l}\text { Internet helps me to solve } \\
\text { my homework }\end{array}$ & 3,91 & 0,81 \\
3 & $\begin{array}{l}\text { Internet helps me to } \\
3,64\end{array}$ & 0,92 \\
\hline
\end{tabular}

\begin{tabular}{llll}
\hline & $\begin{array}{l}\text { prepare my examination } \\
\text { I want to access internet } \\
\text { to find Physics materials } \\
\text { but I do not know how to } \\
\text { find it }\end{array}$ & 2,54 & 1,09 \\
5 & $\begin{array}{l}\text { Internet make me easier } \\
\text { to learn }\end{array}$ & 3,66 & 0,89 \\
6 & $\begin{array}{l}\text { Using internet makes me } \\
\text { confuse than helping me } \\
\text { in understanding Physics } \\
\text { Average }\end{array}$ & 2,69 & 1,05 \\
\hline & 3,71 & 0,91 \\
\hline
\end{tabular}

\section{Discussion}

Most students have their own computer/laptop at home, but less than half of them have an internet connection through their computer/laptop. A larger number of students have internet connection through smartphone/mobile phones. Moreover, most of the participants had used internet for 3 years or more $(78.3 \%)$, and almost three-fourth $(74.1 \%)$ accessed internet every day. This finding is relevant to the previous study conducted by Ayub et al. (2014) which also found that students internet access time are different based on level and field of study. Loan (2011) who conducted a comparative study of internet used by rural and urban college students found that as compared from daily to weekly $84.70 \%$ of urban students were frequent users of internet than rural students $(73.95 \%)$. Based on the results, the students used internet in order to solve their problem in doing homework. It was found as the most reason for using the internet $(78.5 \%)$. This finding in line with the previous finding (Deb, 2011) which also noted that students tend to use internet related to their studies as well as social networking. This fact of internet used by students for various reasons may also be related to internet use as a powerful tool and rich information sources for academic works (Chou et al., 2009).

This study reveals that students' internet self-efficacy and perception about internet were high and positive. This finding is in line with previous research which found that learners showed a positive attitude and adequate selfefficacy of internet use (Baturay et al., 2017; John, 2015; Agyei \& Voogt, 2011; Tsai et al., 2011). Zhao et al. also reported that even though students have shown a positive attitude, the technical support and training are also needed in order to guide students' usage (Zhao et al., 2010). ICT self-efficacy is also noted that plays 
an important role in students' computer skill and information literacies (Hatlevik et al., 2018).

\section{CONCLUSION AND SUGGESTIONS}

Based on the result and discussion above, it can be concluded that most students have internet facilities such as computer or laptop and nearly all of them have internet access through mobile phones. For experience in using the internet, most students in Lampung had used internet for more than or equal to 3 years $(78.1 \%)$. High school students participated in this study have three most reasons in accessing the internet: for academic purposes $(90.3 \%)$, for social media activities $(89.5 \%)$, and for entertainment $(68.4 \%)$. In physics subject, the majority of students used internet access to help them solving their homework (78.5\%). However, the most common barriers faced by the students in accessing internet is the issue of internet connection speed. This was also found in another developing country. The study also revealed that students' general internet selfefficacy was in high category (4.0 out of 5) and students' perception about internet for learning physics was also positive (3.71 out of 5 ). The finding is useful to in facilitating scholars and stakeholders of potential to integrate the use of internet in physics teaching practice at senior high school in Lampung.

By using the questions in the survey, researchers are trying to get a better understanding of the patterns of internet access and utilization among high school students undergoing physics learning. In short, the results of the study provide new knowledge and add literature on internet usage in Physics learning process. The study also assessed the general internet self-efficacy of students and students' perception of internet usage in physics learning. It also suggests a practical important finding as helping the stakeholders and government understand the potential of internet-based learning and adjust properly policies considering the findings.

In its limitation, gender differences, as well as differences in students' demographic and grade have not been explored whereas quite many studies reported it in this current study. Wong et al. (2012) reported that gender significantly affects ICT acceptance of individuals.In contrast, Chou et al. have conducted a study to Taiwanese elementary school students' attitude toward the internet which noted that there is no significant difference found between males and females in terms of attitudes (Chou et al., 2009). The finding is in line with the work by Baturay et al. (2017). It suggests that there is no significant gender difference impact on the internet use. Therefore, further study would be conducted to explore students' gender differences in internet self-efficacy and students' perception about internet for learning physics.

\section{REFERENCES}

Abdous, M. H., \& Yoshimura, M. (2010). Learner Outcomes and Satisfaction: A Comparison of Live Video-streamed Instruction, Satellite Broadcast Instruction, and Face-to-face Instruction. Computers \& Education, 55(2), 733-741.

Agyei, D. D., \& Voogt, J. M. (2011). Exploring the Potential of the Will, Skill, Tool Model in Ghana: Predicting Prospective and Practicing Teachers' Use of Technology. Computers \& Education, 56(1), 91-100.

Ayub, A. F. M., Hamid, W. H. W., \& Nawawi, M. H. (2014). Use of Internet for Academic Purposes among Students in Malaysian Institutions of Higher Education. Turkish Online Journal of Educational Technology-TOJET,13(1), 232-241.

Bandura, A. (1993). Perceived Self-efficacy in Cognitive Development and Functioning. Educational Psychologist, 28(2), 117148.

Baturay, M. H., Gökçearslan, Ş., \& Ke, F. (2017). The Relationship among Preservice Teachers' Computer Competence, Attitude towards Computer-assisted Education, and Intention of Technology Acceptance. International Journal of Technology Enhanced Learning, 9(1), 113.

Blonder, R., Jonatan, M., Bar-Dov, Z., Benny, N., Rap, S., \& Sakhnini, S. (2013). Can You Tube It? Providing Chemistry Teachers with Technological Tools and Enhancing Their Self-efficacy Beliefs. Chemistry Education Research and 
Practice, 14(3), 269-285.

Celik, V., \& Yesilyurt, E. (2013). Attitudes to Technology, Perceived Computer Selfefficacy and Computer Anxiety as Predictors of Computer Supported Education. Computers \& Education, 60(1), 148-158.

Chou, C., Yu, S. C., Chen, C. H., \& Wu, H. C. (2009). Tool, Toy, Telephone, Territory, or Treasure of Information: Elementary School Students' Attitudes toward the Internet. Computers \& Education, 53(2), 308-316.

Deb, S. (2011). Effective Distance Learning in Developing Countries using Mobile and Multimedia Technology. International Journal of Multimedia and Ubiquitous Engineering, 6(2), 33-40.

Hatlevik, O. E., Throndsen, I., Loi, M., \& Gudmundsdottir, G. B. (2018). Students' ICT Self-efficacy and Computer and Information Literacy: Determinants and Relationships. Computers \& Education, 118, 107-119.

Jadoon, N. A., Zahid, M. F., Mansoorulhaq, H., Ullah, S., Jadoon, B. A., Raza, A., \& Shahzad, M. A. (2011). Evaluation of Internet Access and Utilization by Medical Students in Lahore, Pakistan. BMC Medical Informatics and Decision Making, 11(1), 37.

John, S. P. (2015). The Integration of Information Technology in Higher Education: A Study of Faculty's Attitude towards IT Adoption in the Teaching Process. Contaduría y Administración, 60, 230-252.

Limaye, R., \& Fotwengel, G. (2015). Use of Internet among Undergraduate Students from Mumbai, India. International Journals of Electronics and Communication Technology, 6(2), 26-28.

Loan, F. A. (2011). Internet Use by Rural and Urban College Students: a Comparative Study. DESIDOC Journal of Library \& Information Technology, 31(6), 431-436.

Miniwatts Marketing Group. (2017). Internet World Stats: Usage and Population
Statistics.

https://www.internetworldstats.com/stats. htm. [Accessed 1 May 2017].

Rhema, A., \& Miliszewska, I. (2014). Analysis of Student Attitudes towards E-learning: The Case of Engineering Students in Libya. Issues in Informing Science and Information Technology, 11(1), 169-190.

Tondeur, J., Van Braak, J., Sang, G., Voogt, J., Fisser, P., \& Ottenbreit-Leftwich, A. (2012). Preparing Pre-service Teachers to Integrate Technology in Education: A Synthesis of Qualitative Evidence. Computers \& Education, 59(1), 134-144.

Tsai, C. C., Chuang, S. C., Liang, J. C., \& Tsai, M. J. (2011). Self-efficacy in Internetbased Learning Environments: A literature Review. Journal of Educational Technology \& Society, 14(4), 222-240.

Tsai, C. C., \& Lin, C. C. (2004). Taiwanese Adolescents' Perceptions and Attitudes regarding the Internet: Exploring Gender Differences. Adolescence, 39(156), 725734.

Tsai, M. J., \& Tsai, C. C. (2003). Information Searching Strategies in Web-based Science Learning: The Role of Internet Self-efficacy. Innovations in Education and Teaching International, 40(1), 43-50.

Uluyol, Ç., \& Şahin, S. (2016). Elementary School Teachers' ICT Use in the Classroom and Their Motivators for Using ICT. British Journal of Educational Technology, 47(1), 65-75.

Wastiau, P., Blamire, R., Kearney, C., Quittre, V., Van de Gaer, E., \& Monseur, C. (2013). The Use of ICT in Education: A Survey of Schools in Europe. European Journal of Education, 48(1), 11-27.

Wong, K. T., Teo, T., \& Russo, S. (2012). Influence of Gender and Computer Teaching Efficacy on Computer Acceptance among Malaysian Student Teachers: An Extended Technology Acceptance Model. Australasian Journal of Educational Technology, 28(7). 11901207.

Wu, Y. T., \& Tsai, C. C. (2006). University 
117 | Vol 5 No 2, August 2019

Students' Internet Attitudes and Internet

Relationship between High School Self-Efficacy: A Study at Three Students' Internet Use in different Universities in Taiwan. Cyberpsychology \& Behavior, 9(4), 441-450.

Zhao, L., Lu, Y., Huang, W., \& Wang, Q. Locations and Their Internet Selfefficacy. Computers \& Education, 55(4), 1405-142. 